\title{
Estimation of plant sampling uncertainty: an example based on chemical analysis of moss samples
}

\author{
Sabina Dołegowska ${ }^{1}$
}

Received: 18 April 2016 / Accepted: 15 August 2016/Published online: 24 August 2016

(C) The Author(s) 2016. This article is published with open access at Springerlink.com

\begin{abstract}
In order to estimate the level of uncertainty arising from sampling, 54 samples (primary and duplicate) of the moss species Pleurozium schreberi (Brid.) Mitt. were collected within three forested areas (Wierna Rzeka, Piaski, Posłowice Range) in the Holy Cross Mountains (south-central Poland). During the fieldwork, each primary sample composed of 8 to 10 increments (subsamples) was taken over an area of $10 \mathrm{~m}^{2}$ whereas duplicate samples were collected in the same way at a distance of 1-2 m. Subsequently, all samples were triple rinsed with deionized water, dried, milled, and digested $\left(8 \mathrm{~mL} \mathrm{HNO}_{3}(1: 1)+1 \mathrm{~mL} 30 \% \mathrm{H}_{2} \mathrm{O}_{2}\right)$ in a closed microwave system Multiwave 3000 . The prepared solutions were analyzed twice for $\mathrm{Cu}, \mathrm{Fe}, \mathrm{Mn}$, and $\mathrm{Zn}$ using FAAS and GFAAS techniques. All datasets were checked for normality and for normally distributed elements $(\mathrm{Cu}$ from Piaski, $\mathrm{Zn}$ from Posłowice, Fe, Zn from Wierna Rzeka). The sampling uncertainty was computed with (i) classical ANOVA, (ii) classical RANOVA, (iii) modified RANOVA, and (iv) range statistics. For the remaining elements, the sampling uncertainty was calculated with traditional and/or modified RANOVA (if the amount of outliers did not exceed $10 \%$ ) or classical ANOVA after Box-Cox transformation (if the amount of outliers exceeded $10 \%)$. The highest concentrations of all elements were found in moss samples from Piaski, whereas the sampling uncertainty calculated with different statistical methods ranged from 4.1 to $22 \%$.
\end{abstract}

Responsible editor: Elena Maestri

Sabina Dołegowska

Sabina.Dolegowska@ujk.edu.pl

1 Geochemistry and the Environment Division, Institute of Chemistry, Jan Kochanowski University, 15G Świętokrzyska St., 25-406 Kielce, Poland
Keywords Pleurozium schreberi (Brid.) Mitt · Trace elements $\cdot$ Sampling uncertainty $\cdot$ Statistical methods

\section{Introduction}

Since the 1960s, monitoring studies using living organisms has been one of the most popular methods used to measure response of individual organism to pollutants and to assess the environmental quality (Čeburnis and Steinnes 2000; Gerhardt 2002; Wolterbeek 2002; Szczepaniak and Biziuk 2003; Burger 2006; Samecka-Cymerman et al. 2006; Zechmeister et al. 2006). Among the wide and spread group of organisms, some moss species, e.g., Pleurozium schreberi, Hylocomium splendens, Hypnum cupressiforme, and Pseudoscleropodium purum have successfully been used as bioindicators of trace elements (Kaasik and Liiv 2007; Batzias and Siontorou 2008; Dragović and Mihailović 2009; González-Miqueo et al. 2010; Kłos et al. 2011; Mariet et al. 2011) including rare earth elements (Chiarenzelli et al. 2001; Dołegowska and Migaszewski 2013), organic pollutants (Chiarenzelli et al. 2001; Orliński 2002; Ares et al. 2009; Foan et al. 2010; Dołegowska and Migaszewski 2011), and isotopes (Wadleigh 2003; Liu et al. 2008; Xiao et al. 2010; Migaszewski et al. 2010; Liu et al. 2011; Castorina and Masi 2015).

Environmental monitoring is a complex process which consists of many interdependent steps, so we must be aware about errors that can be introduced during a sequential treatment of sample. Each step from selection of sampling sites through sampling to chemical analysis and data interpretation has to be thought over, and all errors that come out at each of these stages should be identified and well recognized because they can be a source of partial uncertainty (Wolterbeek and Verburg 2002; Pasławski and Migaszewski 2006; Sakalys et al. 2009; Kłos et al. 2011, 2012). 
In the environment, the concentration of a single element is determined by a multitude processes that may overlap and make the interpretation of results much harder. The most important parameter that describes the quality of measurement is the measurement uncertainty that involves sampling and chemical analysis (Ramsey and Ellison 2007). According to Ramsey (1998), the total uncertainty (expressed as a standard deviation) is a sum of geochemical and measurement uncertainty whereas the measurement uncertainty is a sum of sampling and analytical uncertainty. In this approach, the analytical uncertainty refers to within-analysis of variance while the sampling uncertainty describes within-location variance (Dołegowska et al. 2015). Today, the assessment of analytical uncertainty is a routine step in the analytical process whereas the assessment of uncertainty in relation to sampling may be much more problematic. The lack of information about error sources induced by plant sampling has a significant effect on interpretation and comparison of analytical results. Chemical analysis of one sample or two (primary and duplicate) samples collected within one sampling site at a distance of 1 to $2 \mathrm{~m}$ may give various results. Differences in element concentrations within sampling site, in other words, between primary and duplicate samples may considerably affect the final result. The error related to sampling may even reach $70-80 \%$, so the estimation of sampling uncertainty is a crucial task (Ramsey and Ellison, 2007). The sample cannot be treated as an individual unrelated to sampling site and sampling procedure. Its chemistry depends on many individual and environmental factors which are beyond our control, but we can decide about type of sampling procedure and its consistency. According to Pasławski and Migaszewski (2006), the sampling uncertainty among all components has the greatest contribution to the measurement uncertainty and it should not exceed $30 \%$ whereas in practice the ratio $s_{\text {meas }}^{2} / s_{\text {total }}^{2}$ should be lower than $20 \%$ (Zhou et al. 2014). Understanding the relationship between element concentration and (i) environmental, physiological, and genetic factors, or (ii) sampling parameters, is a key to proper interpretation of results.

The most popular method used for calculation of sampling uncertainty is a one-way analysis of variance, which is based on the assumption that all data are normally distributed. However, many authors have indicated (Reimann and Filzmoser 2000) that this requirement is rarely fulfilled, so much more popular is a robust equivalent of classical analysis, known as the RANOVA method, which is more resistant to extreme values. Both these methods define the variance as the square of the standard deviation. However, the robust analysis of variance is down-weighting the outliers during the calculation process, so it can give more reliable results when the data show distribution that diverges from normality (Rostron and Ramsey 2012). Another, but less frequently used, is a range statistics method. It is based on the difference between the lowest and highest values. Like the one-way ANOVA, it requires a normally distributed dataset, so it can be used when the element concentration does not vary significantly within the sampling position. The one-way ANOVA and range statistics can be applied only if the preliminary assumption of normal distribution is fulfilled, whereas the RAVONA statistics is employed when the amount of outliers in a dataset does not exceed $10 \%$ of the total results. In any other case, the data have to be transformed to achieve normality. However, the interpretation of results can be problematic despite having performed the back-transformation of obtained results (Dołegowska et al. 2015).

The aims of the present study were to (i) highlight the differences in selected element concentrations determined in the moss species P. schreberi (Brid.) Mitt. collected within three forested areas and (ii) compute and compare the level of uncertainty arising from sampling using one-way ANOVA, classical and modified RANOVA, and range statistics.

\section{Experimental}

\section{Study area and fieldwork}

The city of Kielce is the capital of the Świettokrzyskie province. It is located in the south-central part of Poland, in the central part of the Holy Cross Mountains (HCM). The HCM belong to a separate climatic region with average annual temperatures lower compared to surrounding lowlands. The city is situated within hills and valleys surrounded by forests; hence, this localization gives a great opportunity to conduct biomonitoring studies with naturally growing moss species. For the purpose of this study, three different wooded areas were selected (Fig. 1): (1) Wierna Rzeka located $37 \mathrm{~km}$ west of Kielce, selected as a pristine and a reference area (Dołęgowska et al. 2013); (2) Piaski situated in the northwesternern part of the city near the penitentiary and the local Kielce-Zagnańsk road; and (3) the Posłowice Range surrounding the southwestern part of the city, close to the Barwinek and Baranówek housing developments and the main road 762. Fieldwork was carried out in September of 2014. A total of 54 composite and duplicate samples of the moss species P. schreberi (Brid.) Mitt. were collected within the selected areas. Each composite sample consisted of 8 to 10 increments taken over an open space area of $10 \mathrm{~m}^{2}$ and mixed up to make a single sample. Duplicate samples were collected at a distance of 1 to $2 \mathrm{~m}$, using the same sampling protocol (Jung and Thornton 1997). Only apical green parts of moss samples were collected, subsequently in situ cleaned from foreign organic material, placed in disposable polyethylene bags, and transported to the laboratory. To avoid influence of stemflow and throughfall, samples were collected outside of the crown projection of trees. 


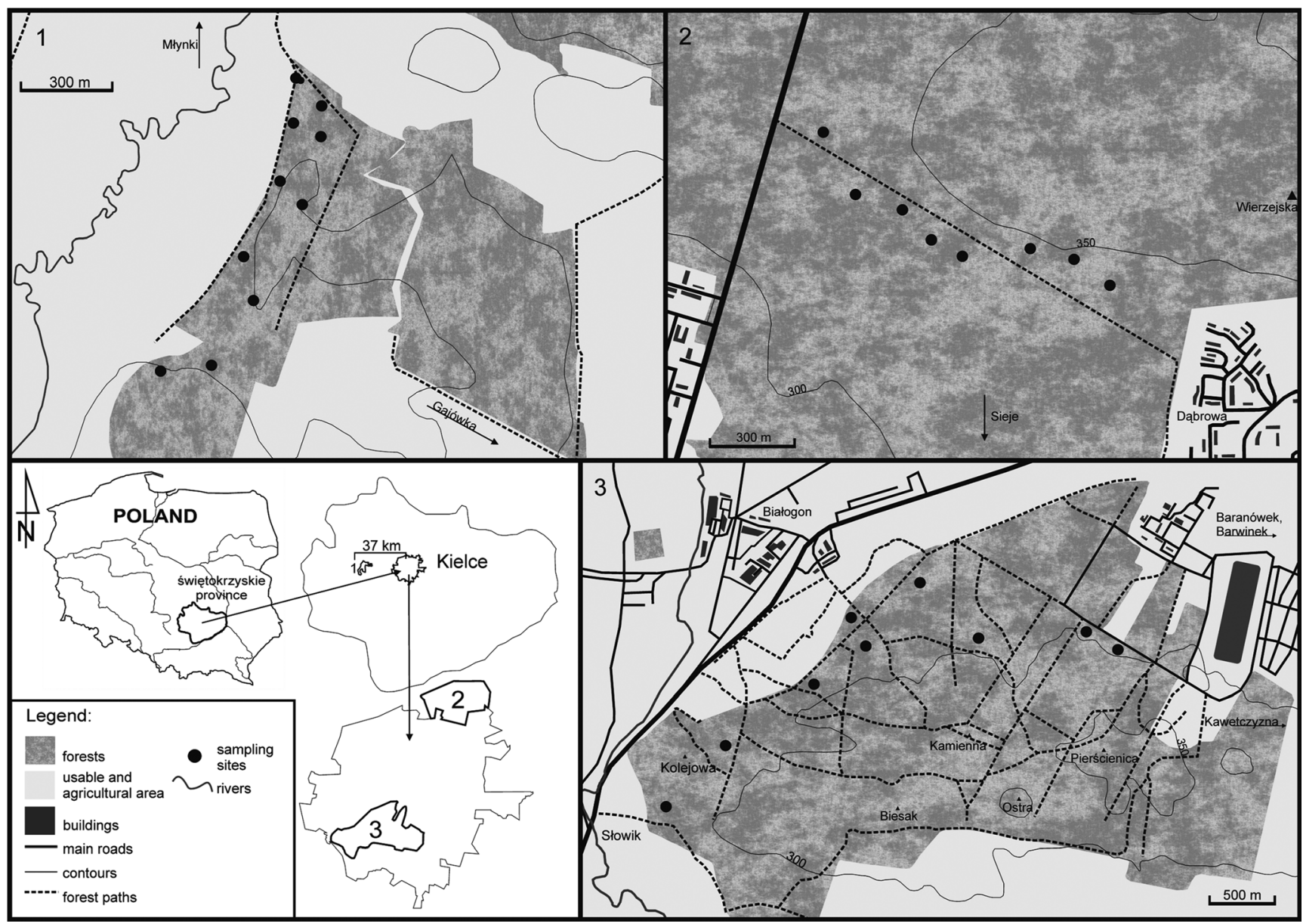

Fig. 1 Localization of investigation sites. 1-Wierna Rzeka. 2-Piaski. 3-Posłowice Range

\section{Sample preparation and chemical analysis}

At the laboratory, samples were stored at an ambient temperature (about $20^{\circ} \mathrm{C}$ ). After drying, the moss samples were triple rinsed with deionized water to remove outer contamination such as cobwebs, pollens, loosely attached mineral particles, and tiny organic material followed by drying at an ambient temperature. To avoid changes in the equilibrium of extracellular-bound cations, the time of rinsing was less than 30 s (Fernández et al. 2015).

Subsequently, samples were milled in an IKA WERKE laboratory mill to a pass $<0.5-\mathrm{mm}$ sieve and digested in a closed microwave system Multiwave 3000 using $\mathrm{HNO}_{3}$ $(1: 1) / \mathrm{H}_{2} \mathrm{O}_{2}$ solution in the ratio of $8 \mathrm{~mL} / 1 \mathrm{~mL}$. The digested samples were analyzed twice for $\mathrm{Fe}, \mathrm{Mn}$, and $\mathrm{Zn}$ using the FAAS technique and for $\mathrm{Cu}$ using the GFAAS technique (THERMO SCIENTIFIC model iCE $3500 Z$ spectrometer). Instrumental and data acquisition parameters of the digestion and AAS instrument are summarized in Table 1. As a standard reference material, tomato leaves (SRM-1573a) were used for quality control purposes. During the analysis, the recalibration process was done after a series of 10 samples analyzed. Recovery, limit of quantification (LOQ), and limit of determination (LOD) are presented in Table 1. The analytical bias was also calculated to confirm that it was not a significant part of uncertainty.

\section{Statistical analysis}

The statistical proceeding included several steps that allowed for estimation of sampling uncertainty with all precautions (Fig. 2). In the RANOVA method, the outlying values are defined as values exceeding the relation mean $\pm c \cdot \sigma_{r}$ (where $\sigma_{r}$ is a robust standard deviation) and during the calculation process, these are replaced by it, whereas the presence of outlying values in a dataset strongly affects the average value and change the measurement precision. To avoid the direct relation to the arithmetic mean, the outlying values were also identified by the median $\pm 2 \cdot \sigma_{r}$ and during the calculation process, these were replaced by it. Subsequently, the median (if it changed) and the robust standard deviation were recalculated. After each operation, the histograms were made and datasets were tested for normality. The statistical operation was repeated as $p$ value (calculated with Shapiro-Wilk test) was constant, or when normality was achieved. 
Table 1 Parameters of digestion process and AAS instrument

\begin{tabular}{|c|c|c|c|c|c|c|}
\hline \multicolumn{2}{|l|}{ Digestion parameters } & \multirow{2}{*}{$\begin{array}{l}\text { Technique } \\
\text { Type of work }\end{array}$} & \multirow{2}{*}{$\begin{array}{l}\text { Fe } \\
\text { Flame } \\
\text { Absorption }\end{array}$} & \multirow[t]{2}{*}{$\mathrm{Mn}$} & \multirow[t]{2}{*}{$\mathrm{Zn}$} & \multirow{2}{*}{$\begin{array}{l}\mathrm{Cu} \\
\text { Cuvette }\end{array}$} \\
\hline Power & $1000 \mathrm{~W}$ & & & & & \\
\hline Time & $65 \mathrm{~min}$ & Wave length & $248.3 \mathrm{~nm}$ & $279.5 \mathrm{~nm}$ & $213.9 \mathrm{~nm}$ & $324.8 \mathrm{~nm}$ \\
\hline Time of growth & 15 & Type of flame & $\mathrm{C}_{2} \mathrm{H}_{2}$ & & & - \\
\hline Time of real digestion & 30 & Type of purge gas & - & & & $\mathrm{Ar}$ \\
\hline Time of cooling & 20 & Gas flow & $0.9 \mathrm{~L} \mathrm{~min}-1$ & $1.0 \mathrm{~L} \mathrm{~min}^{-1}$ & $0.8 \mathrm{~L} \mathrm{~min}^{-1}$ & $0.2 \mathrm{~L} \mathrm{~min}^{-1}$ \\
\hline Temperature & $220^{\circ} \mathrm{C}$ & Background correction & D2 & & & Zeeman \\
\hline Pressure & $6 \mathrm{MPa}$ & Gap & $0.2 \mathrm{~nm}$ & & & $0.5 \mathrm{~nm}$ \\
\hline \multirow[t]{2}{*}{$p$ growth rate } & $0.03 \mathrm{MPa} \mathrm{s}^{-1}$ & Replicates & 3 & & & \\
\hline & & Matrix modifier & - & - & - & $1 \% \mathrm{NH}_{4} \mathrm{NO}_{3}$ \\
\hline \multirow[t]{6}{*}{ Reagents } & $\begin{array}{l}\mathrm{HNO}_{3}(1: 1) 8 \mathrm{~mL} \\
\mathrm{H}_{2} \mathrm{O}_{2} 1 \mathrm{~mL}\end{array}$ & $\begin{array}{l}\text { Concentration range of } \\
\text { standard solutions }\end{array}$ & $0.5-6.0 \mathrm{mg} \mathrm{L}^{-1}$ & $0.1-2.0 \mathrm{mg} \mathrm{L}^{-1}$ & $0.05-0.50 \mathrm{mg} \mathrm{L}^{-1}$ & $1-10 \mu g \mathrm{~L}^{-1}$ \\
\hline & & & & $0.5-6.0 \mathrm{mg} \mathrm{L}^{-1}$ for Piaski & & \\
\hline & & LOD & $0.05 \mathrm{mg} \mathrm{L}^{-1}$ & $0.01 \mathrm{mg} \mathrm{L}^{-1}$ & $0.004 \mathrm{mg} \mathrm{L}^{-1}$ & $0.06 \mu \mathrm{g} \mathrm{L}^{-1}$ \\
\hline & & LOQ & $0.15 \mathrm{mg} \mathrm{L}^{-1}$ & $0.03 \mathrm{mg} \mathrm{L}^{-1}$ & $0.01 \mathrm{mg} \mathrm{L}^{-1}$ & $0.18 \mu \mathrm{g} \mathrm{L}^{-1}$ \\
\hline & & Analytical bias & $-0.02 \mathrm{mg} \mathrm{L}^{-1}$ & $-0.02 \mathrm{mg} \mathrm{L}^{-1}$ & $-0.002 \mathrm{mg} \mathrm{L}^{-1}$ & $-0.02 \mu \mathrm{g} \mathrm{L}^{-1}$ \\
\hline & & Recovery (\%) & $97 \%$ & $98 \%$ & $99 \%$ & $98 \%$ \\
\hline
\end{tabular}

\section{Results and discussion}

Table 2 shows minimum, maximum, mean, and standard deviation values computed for the elements determined in $P$. schreberi moss samples derived from three selected areas. Some statistical parameters such as $p$ values (95\%) computed by Shapiro-Wilk test, skewness, and robust coefficient of variance $\left(\mathrm{CV}_{r}\right)$ were also calculated. The sampling uncertainty expressed as a relative standard deviation $\left(s_{r \text { samp }}(\%)\right)$ calculated for $\mathrm{Cu}, \mathrm{Fe}, \mathrm{Mn}$ and $\mathrm{Zn}$ using various statistical methods is presented in Table 3.

\section{Differences in element concentrations between study areas}

All the determined elements are life-essential for plants (Grodzińska et al. 2003), for example, Zn regulates biomass growth whereas Mn plays a role in oxidation/reduction processes and electron transport in photosynthesis. This also activates many enzymes and imposes Fe deficiency. Fe is a component of enzymes and proteins; it is responsible for respiration and photosynthesis as a factor regulating a synthesis of chlorophyll. In plants, copper regulates many physiological processes and is a factor of metalloproteins (Miller et al. 1995; Hafeez
Fig. 2 Scheme of statistical proceeding

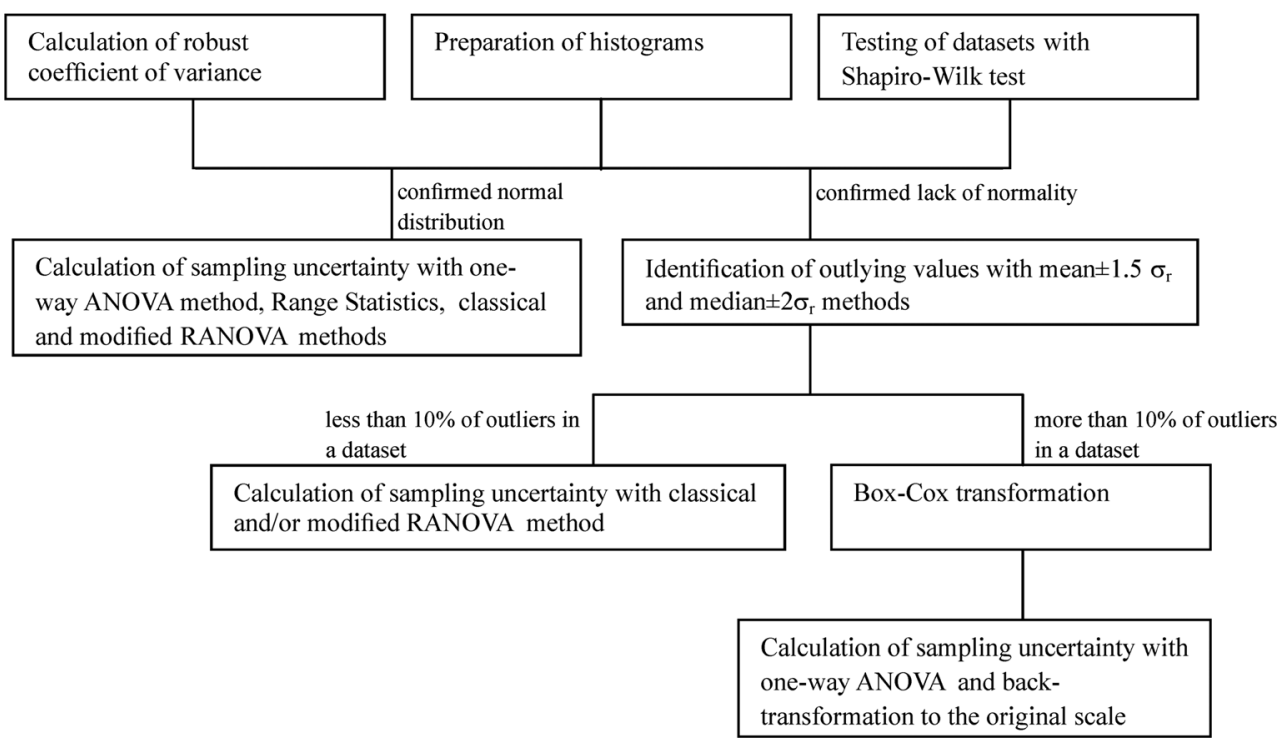




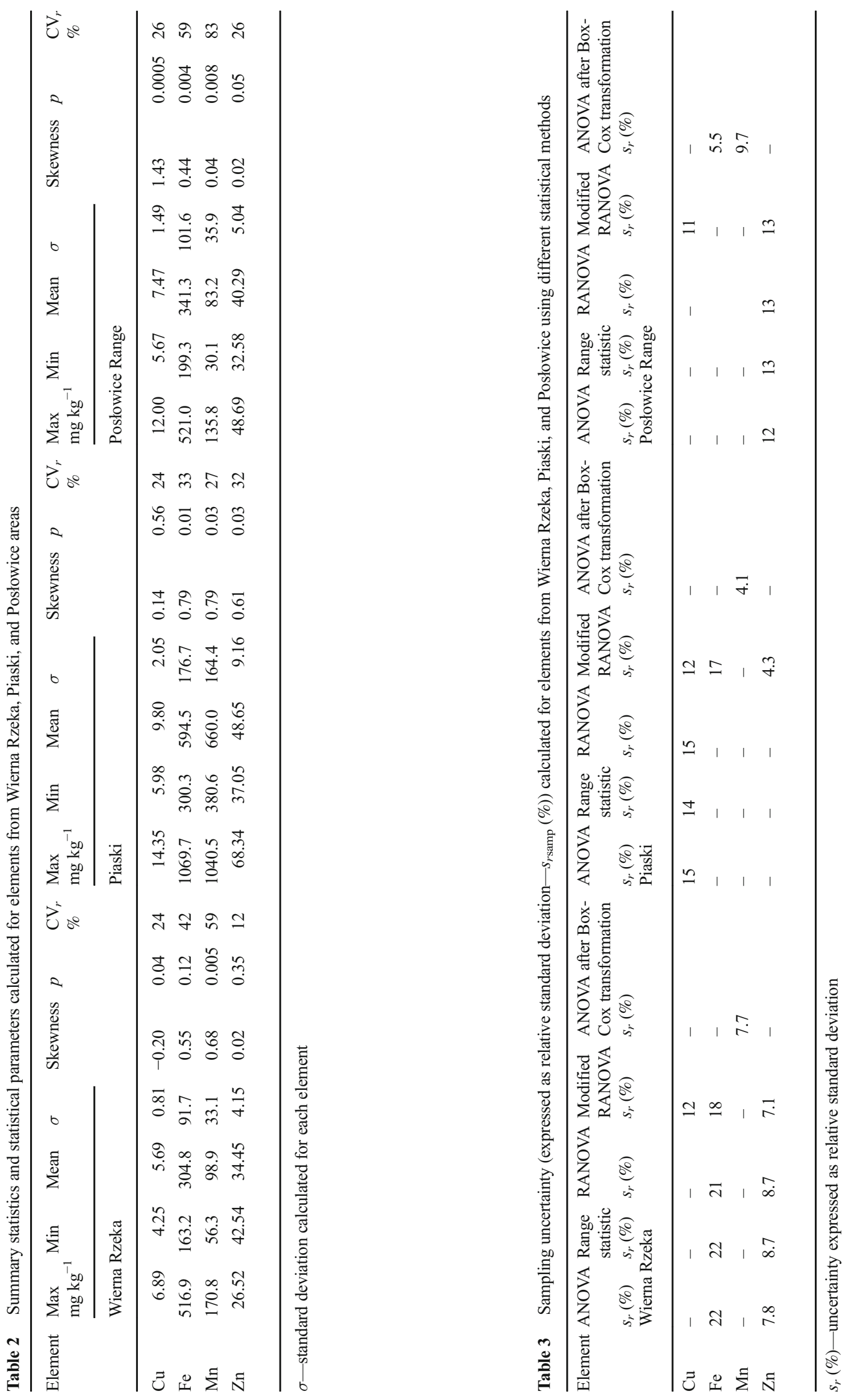


et al. 2013; Sadeghzadeh 2013). According to moss bioindicative properties, the higher content of this element in the air is the higher its concentration in moss tissues. In this study, the moss samples from Piaski were enriched in all the elements examined. The Mn content was even three times higher than in samples from Posłowice and Wierna Rzeka (Table 2). The concentration of Mn in lichens Hypogymnia physodes and 1- and 2-year-old pine needles collected at nearby Wierzejska Mt. (375 m a.s.l.) in 1994 and 1995 were as follows: lichens (sampled from different trees) - 53 and $144 \mathrm{mg} \mathrm{kg}^{-1}$ and needles - depending on needle age- 320 and $455 \mathrm{mg} \mathrm{kg}^{-1}$ (Migaszewski and coauthors, unpubl. data). The chemical analysis of $P$. schreberi samples performed in 2009 also gave much lower levels, 219 and $234 \mathrm{mg} \mathrm{kg}^{-1}$, respectively (Dołegowska et al. 2013). These differences may arise from a negative correlation between element concentrations and altitude. However, the results derived from this study are not unequivocal (Sucharová and Suchara 2004; Coşkun et al. 2005; Gerdol and Bragazza 2006). The mean concentration of $\mathrm{Mn}$ in the moss species H. splendens and P. schreberi from the Holy Cross Mountains reported by Gałuszka (2007) was $364 \mathrm{mg} \mathrm{kg}^{-1}$. The average content of $\mathrm{Mn}(660 \mathrm{mg} / \mathrm{kg})$ in moss samples from Piaski is much higher than that noted in mosses from other regions of Poland: Silesia-Kraków$145 \mathrm{mg} \mathrm{kg}^{-1}$, Legnica-Głogów-278 $\mathrm{mg} \mathrm{kg}^{-1}$ (Grodzińska et al. 2003), Stalowa Wola- $250 \mathrm{mg} \mathrm{kg}^{-1}$ (SameckaCymerman et al. 2006), or neighboring countries: Russia$300 \mathrm{mg} \mathrm{kg}^{-1}$ (Ermakova et al. 2004), Czech Republic$416 \mathrm{mg} \mathrm{kg}^{-1}$ (Sakalys et al. 2009), Germany-331 $\mathrm{mg} \mathrm{kg}^{-1}$ (Siewers et al. 2000), Lithuania-273 $\mathrm{mg} \mathrm{kg}^{-1}$ (Čeburnis and Steinnes 2000), and also in Macedonia- $186 \mathrm{mg} \mathrm{kg}^{-1}$ (Barandovski et al. 2008), Bułgaria- $251 \mathrm{mg} \mathrm{kg}^{-1}$ (Stamenov et al. 2002), and Spain-285 mg kg-1 (S. purum) and $210 \mathrm{mg} \mathrm{kg}^{-1}$ (H. cupressiforme) (Fernández and Carballeira 2002). The similar average values were noted only in mosses from Norway-542 $\mathrm{mg} \mathrm{kg}^{-1}$ (Reimann et al. 2006) and France- $712 \mathrm{mg} \mathrm{kg}^{-1}$ (Leblond et al. 2004). The concentrations of trace elements in the mosses may vary with time because of a selective loss of elements, but Mn enrichment results predominantly from increased Mn cycling in forest ecosystems. Along with $\mathrm{Zn}, \mathrm{Mn}$ occurs in throughfall in a dissolved fraction, so the enrichment may also come from the recretion of the canopy (Gandois et al. 2010a). What is more, Mn shows a strong affinity for organic matter, so it can be retained in moss tissues in higher concentrations.

The comparison of $\mathrm{Fe}, \mathrm{Mn}, \mathrm{Cu}$, and $\mathrm{Zn}$ concentrations in various tissues of Pinus sylvestris shows that $\mathrm{Mn}$ and $\mathrm{Zn}$ accumulate mainly in 2- and 3-year-old needles whereas $\mathrm{Fe}$ in pine bark (Pasławski and Migaszewski 2006). Dragović and Mihailović (2009) reported that $\mathrm{Mn}$ and $\mathrm{Zn}$ accumulate in mosses by leaching from higher plants (and additionally from throughfall); this process is another significant source of these elements. In practice, to avoid the influence of throughfall and leaching from higher plants on moss chemistry, samples should be collected, if possible, in open space areas.

The enrichment in Mn and $\mathrm{Zn}$ observed in the mosses from Piaski is also induced by different soil conditions (acidity). The average $\mathrm{pH}_{\mathrm{CaCl}_{2}}$ of soil samples from Piaski is 3.1, whereas of soils from Posłowice and Wierna Rzeka 4.1 and 4.2, respectively. The lower $\mathrm{pH}$ makes these elements more mobile and bioavailable (Gandois et al. 2010b). Mosses do not have a root system; therefore, these elements are transported with airborne soil particles and adsorbed onto mosses; this is the reason why they can be much easier washed into moss tissues. Another aspect that should be taken under consideration is a probable correlation between moss occurrence and bioaccumulation process. Pesch and Schröder (2006) noticed that rare moss occurrence is accompanied by high bioaccumulation process and vice versa. Of the three study areas (Piaski, Posłowice, and Wierna Rzeka), the Piaski area is characterized by the lowest moss coverage and the highest environmental degradation. The soil profile is shallow and underdeveloped. The poorer soil coverage increases the amount of particles that may be freely transported and deposited onto moss tissues. The same relationship between the stable sulfur isotope signature and moss coverage was also reported by Migaszewski et al. (2010). Where the coverage of the moss carpet was extensive, the $\delta^{34} \mathrm{~S}$ values were high, and vice versa. Sites with thick tangled moss mats showed the lowest $\delta^{34} \mathrm{~S}$ and a lack of distinct isotope diversity between the moss species $H$. splendens and $P$. schreberi, and vice versa. The diverse moss density may also result from various microclimatic and edaphic conditions (Holy et al. 2009).

Pasławski and Migaszewski (2006) found the highest concentrations of $\mathrm{Fe}$ in the pine bark and epiphytic lichens growing on these trees and the lowest in the pine needles and roots. The significant disproportionation between the element content and various tissues was not observed for $\mathrm{Cu}$. However, the highest concentrations of this metal were observed in the 1-year pine needles. Both $\mathrm{Fe}$ and $\mathrm{Cu}$ represent the soil contribution and are accumulated by higher plants from dry deposition. Except for throughfall, dry deposition was also reported by Dragović and Mihailović (2009) as a main source of Fe and $\mathrm{Cu}$ in mosses. The content of $\mathrm{Fe}$ in the moss samples from the Posłowice Range and Wierna Rzeka is similar to that reported for national parks of Poland (Grodzińska et al. 1999) and other Central-European countries (Harmens et al. 2010). By contrast to Posłowice and Wierna Rzeka, the samples from Piaski were enriched in this element. The higher concentrations of $\mathrm{Fe}$ were close to those found in industrial regions of Poland (1226 mg kg${ }^{-1}$ ) and some European countries (Belgium, Slovenia, Italy, and France). The levels of $\mathrm{Cu}$ 
(Table 2) were in turn typical of those noted in mosses from the other European regions (Grodzińska et al. 2003; Harmens et al. 2010).

The element concentrations in the mosses from Posłowice and Wierna Rzeka fall into the following concentration sequence: $\mathrm{Fe}>>\mathrm{Mn}>\mathrm{Zn}>\mathrm{Cu}$ whereas in the moss samples from Piaski, this element trend is different: $\mathrm{Mn}>\mathrm{Fe}>\mathrm{Zn}>$ $\mathrm{Cu}$. The same Posłowice and Wierna Rzeka sequence revealed the moss samples collected from other parts of the HCM (Gałuszka 2007; Dołegowska et al. 2013), and throughout the world, e.g., Serbia (Dragović and Mihailović 2009), Romania (State et al. 2012), France (Gandois et al. 2014), Finland (Salo et al. 2012), and Argentina (Wannaz et al. 2012).

There is no correlation between the coefficient of variation and the concentration level. The robust coefficient of variation $\left(\mathrm{CV}_{r}\right)$ calculated for all the determined elements varied from 12 to $83 \%$. The highest variability was noted for $\mathrm{Mn}$ and $\mathrm{Fe}$ from Posłowice (83 \%, $59 \%$ ) and Mn from Wierna Rzeka (59 \%). The results below $30 \%$ were obtained for $\mathrm{Cu}$ and $\mathrm{Zn}$ from Posłowice (26\%) and Wierna Rzeka (24\%, $12 \%)$ and for $\mathrm{Cu}$ and $\mathrm{Mn}$ from Piaski $(24 \%, 27 \%)$. The $\mathrm{CV}_{r}$ values for the remaining elements were in the range of 30 to $42 \%$. The highest coefficient of variation computed for the moss samples from the Kielce region was also noted for $\mathrm{Mn}-61 \%$ whereas for $\mathrm{Cu}, \mathrm{Fe}$, and $\mathrm{Zn}$ averaged around $20 \%$ (Dołegowska et al. 2013). The highest variability of $\mathrm{Mn}$ in mosses was also observed by Gałuszka (2007) (about $100 \%$ ) and by Reimann et al. (2006) (64\%).

\section{Sampling uncertainty}

Sampling is one of the most important contributions to the uncertainty (Ramsey and Thompson 2007; Dołegowska and Migaszewski 2015). It is a part of measurement uncertainty and can be calculated as a difference between measurement and analysis sum of square (Ramsey 1998). To prove that chemical analysis was not a significant source of uncertainty, the analytical bias was also calculated (Table 1). Moreover, to reduce the analytical bias, the equipment was checked and calibrated properly for the range of expected values (Table 1). According to the literature, the analytical method is fit for purpose when the $s^{2}$ anal is less than $20 \%$ of $s^{2}$ meas (Ramsey et al. 1992). For all the elements examined, this relation was met, so the analytical procedure was fit for purpose and was not a significant source of uncertainty.

As mentioned before, the classical analysis of variance can be applied when the datasets fulfill the assumption of normality; otherwise, robust models need to be used or data need to be transformed. Rejection of outlying values is not recommended because in environmental studies, they may carry a crucial information about the study area and potential "hot spots" (Gałuszka et al. 2015). In this study, computed coefficients of skewness and shapes of histograms confirmed asymmetrical distribution of the majority of analyzed elements (Table 2). The normal distribution was only approached for $\mathrm{Cu}$-Piaski, $\mathrm{Zn}$-Posłowice, and Fe and $\mathrm{Zn}$ - Wierna Rzeka. Therefore, only for these elements, the sampling uncertainty was computed with the one-way ANOVA, range statistics, traditional, and modified RANOVA methods. The lowest $s_{r \text { samp }}$ values (except for Zn-Posłowice) were obtained with modified RANOVA method but the differences between all values were in the range of 1 to $4 \%$ (Table 3). The comparison of classical ANOVA and RANOVA showed that higher values were typically given by RAVONA whereas the range statistics method gives intermediate values (except for $\mathrm{Cu}$-Piaski).

The same relationship was noted by the other authors (Gron et al. 2007; Zhou et al. 2014), but as shown by Dołegowska et al. (2015), it is not always preserved. However, it should be stressed that most studies have encompassed soil or food samples. The uncertainty arising from plant sampling was computed by Smagunova et al. (2004) and Lyn et al (2007). Pasławski and Migaszewski (2006) reported that the uncertainty of sampling should not exceed $20 \%$, but usually is in the range of 10 to $30 \%$, whereas Ramsey et al. (1992) assumed that if the whole procedure is to be fit for purpose, the combined sampling and analytical variances (measurement variances) for the data must comprise less than $20 \%$ of the total variance. In this study, the sampling uncertainty higher than $20 \%$ was obtained for Fe from Wierna Rzeka. These results are consistent with the high robust coefficient of variance ( $42 \%$ ), so it can be expected that the high sampling uncertainty arises from the large variability of this element in the environment and not from incorrect sampling. The same relationship was found for $\mathrm{Zn}$ from Wierna Rzeka where the lowest sampling uncertainty $(7.1 \%)$ corresponded with the lowest coefficient of variation (12\%). As for $\mathrm{Zn}$ from Posłowice and $\mathrm{Cu}$ from Piaski, the sampling uncertainty was in the range of $12-13$ and $12-15 \%$, respectively. For these two elements, the robust coefficient of variation was 26 and $24 \%$.

With respect to $\mathrm{Fe}$ and $\mathrm{Zn}$ from Piaski and $\mathrm{Cu}$ from Posłowice and Wierna Rzeka, the data distribution diverged from normal. The amount of outlying values identified with mean $\pm 1.5 \sigma_{r}$ (where $\sigma_{r}$ is a robust standard deviation) exceeded $10 \%$, whereas that identified with median $\pm 2 \sigma_{r}$ was below $10 \%$, so to avoid data transformation, the sampling uncertainty was computed with the modified RANOVA method (using median $\pm 2 \sigma_{r}$ instead of mean $\pm 1.5 \sigma_{r}$ ) (Table 3 ). The

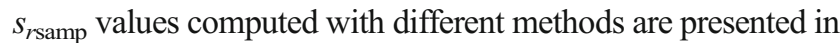
Table 3. The highest uncertainty was noted for Fe and the lowest for $\mathrm{Zn}$. It is interesting to note that $\mathrm{Zn}$ and $\mathrm{Fe}$ have a higher coefficient of variation compared to $\mathrm{Cu}$. The dispersion of results lead to a greater difference between mean and median values; hence, the higher differences are found between the $s_{r \text { samp }}$ values. The same results were obtained by Smagunova 
et al. (2004). These authors found the highest sampling uncertainty for $\mathrm{Fe}(20-25 \%)$ and $\mathrm{Mn}(9.9-33 \%)$, whereas the lowest for $\mathrm{Zn}$ (about $7.7 \%$ ). The analysis of duplicate samples of spruce needles gave the sampling uncertainty of $13 \%$ for $\mathrm{Mn}$ and $6 \%$ for $\mathrm{Zn}$ (Čeburnis and Steinnes 2000). However, the highest uncertainty exceeding $25 \%$ was obtained for As (29\%) and $\mathrm{V}(21 \%)$

In general, the robust statistical techniques are more adequate for analysis of environmental results. These datasets are scarcely devoid of extreme values and their presence arises mainly from natural geochemical diversity. The use of median $\pm c \cdot \sigma_{r}$ instead of mean $\pm c \cdot \sigma_{r}$ during the calculation process allows us to avoid the direct relationship with the arithmetic mean, which is strongly dependent on outliers.

In case of $\mathrm{Fe}$ and $\mathrm{Mn}$ from Posłowice and Mn from Piaski and Wierna Rzeka, the number of outliers exceeded $10 \%$ of the total results (identified with mean $\pm 1.5 \sigma_{r}$ and median \pm $2 \sigma_{r}$ ); therefore, the datasets were transformed using the BoxCox function. To compare the sampling uncertainty (computed with the transformed data) with the values obtained for the raw dataset, the back-transformation process was conducted. The sampling uncertainty computed for the transformed data with the one-way ANOVA method was $5.5 \%$ for $\mathrm{Fe}$ and ranged from 4.1 to $9.7 \%$ for Mn (Table 3). The $s_{r \text { samp }}$ values were much lower compared to those obtained for the raw data. However, the relationship between the lower coefficient of variance and the lower sampling uncertainty was kept. As shown by Dołegowska et al. (2015), the transformation reduces non-normality, but gives a completely different dataset. The use of back-transformation allows comparison of results with raw data. Nonetheless, this introduces another operation on the data. It is noteworthy that the use of $\log _{10} \mathrm{x}$ transformation gave the $s_{r \text { samp }}$ at the same level. The Box-Cox function was much suitable and allowed for achieving normality for all the datasets tested. The $\log _{10} \mathrm{x}$ transformation failed to restore normality for Fe from Piaski and $\mathrm{Cu}$ from Wierna Rzeka.

\section{Conclusions}

The results derived from this study enable drawing the following conclusions:

1. The moss samples from Piaski were enriched in all the elements examined and the Mn concentrations were even three times higher than those in samples from Posłowice and Wierna Rzeka. This enrichment may be linked to a lower soil $\mathrm{pH}$ and sparse moss occurrence.

2. The highest coefficients of variance were noted for $\mathrm{Mn}$ and $\mathrm{Fe}$ from Posłowice and Wierna Rzeka.

3. The following relationship was observed: the higher coefficient of variance, the higher sampling uncertainty.
This relation is logical, although it was not observed for all the elements examined.

4. The comparison of classical ANOVA, RANOVA, and range statistics showed that the $s_{r \text { samp }}$ values computed with the range statistics method (except for $\mathrm{Cu}$ from Piaski) are between those obtained with the other two statistical methods. This method could be more suitable for normally distributed datasets.

5. The comparison of classical and modified RANOVA methods showed that using median $\pm c \cdot \sigma_{r}$ instead of mean $\pm c \cdot \sigma_{r}$ during the calculation process leads to lower $s_{r \text { samp }}$ values. This also enables us to avoid a direct relationship with the arithmetic mean, which is strongly dependent on outliers. This model could be more appropriate for datasets with distribution diverging from normal.

6. The use of Box-Cox transformation helps achieve normality and enables us to calculate uncertainty with the one-way ANOVA method. The back-transformation to the original scale gives the possibility to compare our results with the raw data. This transformation can be used when the others, such as $\log _{10}$ transformation, do not lead to achieve normality.

7. The $s_{r \text { samp }}$ values computed for the transformed data are much lower compared with the raw data (despite the backtransformation process), and their interpretation may be more dubious.

Acknowledgments I would like to thank Professors Z.M. Migaszewski and A. Gałuszka for their assistance during fieldwork and professional guidance that improved the quality of this manuscript.

Open Access This article is distributed under the terms of the Creative Commons Attribution 4.0 International License (http:// creativecommons.org/licenses/by/4.0/), which permits unrestricted use, distribution, and reproduction in any medium, provided you give appropriate credit to the original author(s) and the source, provide a link to the Creative Commons license, and indicate if changes were made.

\section{References}

Ares A, Aboal JR, Fernández JÁ, Real C, Carballeira A (2009) Use of the terrestrial moss Pseudoscleropodium purum to detect sources of small scale contamination by PAHs. Atmos Environ 43:5501-5509. doi:10.1016/j.atmosenv.2009.07.005

Barandovski L, Cekova M, Frontasyeva MV, Pavlov SS, Stafilov T, Steinnes E, Urumov V (2008) Atmospheric deposition of trace element pollutants in Macedonia studied by the moss biomonitoring technique. Environ Monit Assess 138:107-118. doi:10.1007/s10661-007-9747-6

Batzias AF, Siontorou CG (2008) A new scheme for biomonitoring heavy metal concentrations in semi-natural wetlands. J Hazard Mater 158: 340-358. doi:10.1016/j.jhazmat.2008.01.092

Burger J (2006) Bioindicators: a review of their use in the environmental literature 1970-2005. Environ Bioindic 1:136-144. doi:10.1080 $/ 15555270600701540$

Castorina FB, Masi U (2015) Rare earth elements and Sr-Nd isotopes in mosses from Romagna (Italy) and their environmental significance. Biogeochemistry 123:251-263. doi:10.1007/s10533-015-0067-6 
Čeburnis D, Steinnes E (2000) Conifer needles as biomonitors of atmospheric heavy metal deposition: comparison with mosses and precipitation, role of the canopy. Atmos Environ 34:4265-4271. doi:10.1016/S1352-2310 (00)00213-2

Chiarenzelli J, Aspler L, Dunn C, Cousens B, Ozarko D, Powis K (2001) Multi-element and rare earth element composition of lichens, mosses, and vascular plants from the central Barrenlands, Nunavut, Canada. Appl Geochem 16:245-270. doi:10.1016/S0883-2927(00)00027-5

Coșkun M, Frontasyeva MV, Steinnes E, Çotuk AY, Pavlov SS, Coșkun M, Sazonov AS, Çayir A, Belivermis M (2005) Atmospheric deposition of heavy metals in trace studied by analysis of moss (Hypnum cupressiforme). Bull Environ Contam Toxicol 74:201-209. doi:10.1007/s00128-004-0569-8

Dołegowska S, Migaszewski ZM (2011) PAH concentrations in the moss species Hylocomium splendens (Hedw.) B.S.G. and Pleurozium schreberi (Brid.) Mitt. from the Kielce area (south-central Poland). Ecotoxicol Environ Saf 74:1636-1644. doi:10.1016/j. ecoenv.2011.05.011

Dołegowska S, Migaszewski ZM (2013) Anomalous concentrations of rare earth elements in the moss-soil system from south-central Poland. Environ Pollut 178:33-40. doi:10.1016/j.envpol.2013.02.024

Dołegowska S, Migaszewski ZM (2015) Plant sampling uncertainty: a critical review based on moss studies. Environ Rev 23:1-10. doi:10.1139/er2014-0052

Dołęgowska S, Migaszewski ZM, Michalik A (2013) Hylocomium splendens (Hedw.) B.S.G. and Pleurozium schreberi (Brid.) Mitt. as trace element bioindicators: statistical comparison of bioaccumulative properties. J Environ Sci 23:81-87. doi:10.1007/s13398-014-0173-7.2

Dołęgowska S, Gałuszka A, Migaszewski ZM (2015) Assessing soil sampling uncertainty in heterogeneous historic metal ore mining sites. Accredit Qual Assur 20:163-170. doi:10.1007/s00769-015-1109-4

Dragović S, Mihailović N (2009) Analysis of mosses and topsoils for detecting sources of heavy metal pollution: multivariate and enrichment factor analysis. Environ Monit Assess 157:383-390. doi:10.1007 /s10661-008-0543-8

Ermakova EV, Frontasyeva MV, Steinnes E (2004) Air pollution studies in Central Russia (Tula Region) using the moss biomonitoring technique, INAA and AAS. J Radioanal Nucl Chem 259:51-58. doi:10.1023 /B:JRNC.0000015805.22707.al

Fernández JÁ, Carballeira A (2002) Biomonitoring metal deposition in Galicia (NW Spain) with mosses: factors affecting bioconcentration. Chemosphere 46:535-542. doi:10.1016/S0045-6535(01)00060-1

Fernández JA, Boquete MT, Carballeira A, Aboal JR (2015) A critical review of protocols for moss biomonitoring of atmospheric deposition: sampling and sample preparation. Sci Total Environ 517:132-150

Foan L, Sablayrolles C, Elustondo D, Lasheras E, González L, Ederra A, Simon V, Santamaría JM (2010) Reconstructing historical trends of polycyclic aromatic hydrocarbon deposition in a remote area of Spain using herbarium moss material. Atmos Environ 44:3207-3214. doi:10.1016/j.atmosenv.2010.05.019

Gałuszka A (2007) Distribution patterns of PAHs and trace elements in mosses Hylocomium splendens (Hedw.) B.S.G. and Pleurozium schreberi (Brid.) Mitt. from different forest communities: a case study, south-central Poland. Chemosphere 67:1415-1422. doi:10.1016/j. chemosphere.2006.10.010

Gałuszka A, Migaszewski ZM, Dołęgowska S, Michalik A, DuczmalCzernikiewicz A (2015) Geochemical background of potentially toxic trace elements in soils of the historic copper mining area: a case study from Miedzianka Mt., Holy Cross Mountains, south-central Poland. Environ Earth Sci 74:4589-4605. doi:10.1007/s12665-015-4395-6

Gandois L, Probst A, Dumat C (2010a) Modelling trace metal extractability and solubility in French forest soils by using soil properties. Eur J Soil Sci 61:271-286. doi:10.1111/j.1365-2389.2009.01215.x

Gandois L, Tipping E, Dumat C, Probst A (2010b) Canopy influence on trace metal atmospheric inputs on forest ecosystems: speciation in throughfall. Atmos Environ 44:824-833. doi:10.1016/j. atmosenv.2009.11.028

Gandois L, Agnan Y, Leblond S, Séjalon-Delmas N, Le Roux G, Probst A (2014) Use of geochemical signatures, including rare earth elements, in mosses and lichens to assess spatial integration and the influence of forest environment. Atmos Environ 95:96-104. doi:10.1016/j. atmosenv.2014.06.029

Gerdol R, Bragazza L (2006) Effects of altitude on element accumulation in alpine moss. Chemosphere 64:810-816

Gerhardt A (2002) Bioindicator species and their use in biomonitoring. In: Environmental Monitoring Vol. I- UNESCO Encyclopedia of Life Support Systems. UNESCO-EOLSS e-Books and Prints Library, Paris, pp 77-123

González-Miqueo L, Elustondo D, Lasheras E, Santamaría J (2010) Use of native mosses as biomonitors of heavy metals and nitrogen deposition in the surroundings of two steel works. Chemosphere 78:965-971. doi:10.1016/j.chemosphere.2009.12.028

Grodzińska K, Szarek-Lukaszewska G, Godzik B (1999) Survey of heavy metal deposition in Poland using mosses as indicators. Sci Total Environ 229:41-51. doi:10.1016/S0048-9697(99)00071-6

Grodzińska K, Frontasyeva M, Nska KG, Gundorina SF, Klich M, Ostrovnaya TM (2003) Trace element contamination in industrial regions of Poland studied by moss monitoring. Environ Monit Assess 87: 255-270. doi:10.1023/A:1024871310926

Gron C, Hansen JB, Magnusson B, Nordbotten A, Krysell M, Andersen KJ, Lund U (2007) Uncertainty from sampling — a Nordtest handbook for sampling planners on sampling quality assurance and uncertainty estimation. http://www.nordtest.info/index.php/technicalreports/item/uncertainty-from-sampling-a-nordtest-handbook-forsampling-planners-on-sampling-quality-assurance-and-uncertaintyestimation-nt-tr-604.html, 2007.

Hafeez B, Khanif YM, Saleem M (2013) Role of zinc in plant nutrition-a review. Am J Exp Agric 3:374-391. doi:10.9734/AJEA/2013/2746

Harmens H, Norris DA, Steinnes E, Kubin E, Piispanen J, Alber R, Aleksiayenak Y, Blum O, Coșkun M, Dam M, De Temmerman L, Fernández JA, Frolova M, Frontasyeva M, González-Miqueo L, Grodzińska K, Jeran Z, Korzekwa S, Krmar M, Kvietkus K, Leblond S, Liiv S, Magnússon SH, Mankovská B, Pesch R, Rühling A, Santamaria JM, Schröder W, Spiric Z, Suchara I, Thöni L, Urumov V, Yurukova L, Zechmeister HG (2010) Mosses as biomonitors of atmospheric heavy metal deposition: spatial patterns and temporal trends in Europe. Environ Pollut 158:3144-3156. doi:10.1016/j. envpol.2010.06.039

Holy M, Leblond S, Pesch R, Schröder W (2009) Assessing spatial patterns of metal bioaccumulation in French mosses by means of an exposure index. Environ Sci Pollut Res 16:499-507. doi:10.1007/s11356-0090146-0

Jung MC, Thornton I (1997) Environmental contamination and seasonal variation of metals in soils, plants and waters in the paddy fields around a Pb-Zn mine in Korea. Sci Total Environ 198:105-121

Kaasik M, Liiv S (2007) Spatial and temporal variability of trace metals in mosses in Estonia. Forestry Studies|Metsanduslikud Uurimused 46:3544

Kłos A, Rajfur M, Šrámek I, Wacławek M (2011) Use of lichen and moss in assessment of forest contamination with heavy metals in Praded and Glacensis Euroregions (Poland and Czech Republic). Water Air Soil Poll 222:367-376. doi:10.1007/s11270-011-0830-9

Kłos A, Rajfur M, Šrámek I, Wacławek M (2012) Mercury concentration in lichen, moss and soil samples collected from the forest areas of Praded and Glacensis Euroregions (Poland and Czech Republic). Environ Monit Assess 184:6765-6774. doi:10.1007/s10661-011-2456-1

Leblond S, Gombert S, Colin JL, Losno R, Traubenberg CR (2004) Biological and temporal variations of trace element concentrations in the moss species Scleropodium purum (Hedw.) Limpr. J Atmos Chem 49:95-110. doi:10.1007/s10874-004-1217-8 
Liu XY, Xiao HY, Liu CQ, Li YY, Xiao HW (2008) Stable carbon and nitrogen isotopes of the moss Haplocladium microphyllum in an urban and a background area (SW China): the role of environmental conditions and atmospheric nitrogen deposition. Atmos Environ 42:54135423. doi:10.1016/j.atmosenv.2008.02.038

Liu XY, Xiao HY, Liu CQ (2011) Physiological and isotopic signals in epilithic mosses for indicating anthropogenic sulfur on the urban-rural scale. Ecol Indic 11:1245-1250. doi:10.1016/j.ecolind.2011.01.002

Lyn JA, Palestra IM, Ramsey MH, Damant AP, Wood R (2007) Modifying uncertainty from sampling to achieve fitness for purpose: a case study on nitrate in lettuce. Accredit Qual Assur 12:67-74. doi:10.1007/s00769006-0239-0

Mariet C, Gaudry A, Ayrault S, Moskura M, Denayer F, Bernard N (2011) Heavy metal bioaccumulation by the bryophyte Scleropodium purum at three French sites under various influences: rural conditions, traffic, and industry. Environ Monit Assess 174:107-118. doi:10.1007/s10661010-1442-3

Migaszewski ZM, Dołegowska S, Hałas S, Trembaczowski A (2010) Stable sulfur isotope ratios in mosses Hylocomium splendens (Hedw.) B.S.G. and Pleurozium schreberi (Brid.) Mitt. from the Kielce area (southcentral Poland). Isot Environ Healt S 46(2):219-224. doi:10.1080 /10256016.2010.488725

Miller GW, Huang IJ, Welkie GW, Pushnik JC (1995) Function of iron in plants with special emphasis on chloroplasts and photosynthetic activity. In: Abadía J (ed) Iron nutritions in soils and plants. Springer Science + Bussiness Media B.V, Berlin, pp 19-28

Orliński R (2002) Multipoint moss passive samplers assessment of urban airborne polycyclic aromatic hydrocarbons: concentrations profile and distribution along Warsaw main streets. Chemosphere 48:181-186. doi:10.1016/S0045-6535(02)00062-0

Pasławski P, Migaszewski ZM (2006) The quality of element determinations in plant materials by instrumental methods. Pol J Environ Stud 15(2A): 154-164

Pesch R, Schröder W (2006) Integrative exposure assessment through classification and regression trees on bioaccumulation of metals, related sampling site characteristics and ecoregions. Ecol Inform 1:55-65. doi:10.1016/j.ecoinf.2005.10.007

Ramsey MH (1998) Sampling as a source of measurement uncertainty: techniques for quantification and comparison with analytical sources. J Anal At Spectrom 13:97-104. doi:10.1039/a706815h

Ramsey MH, Ellison SLR (eds) (2007) Eurachem/EUROLAB/CITAC/ Nordtest/AMC Guide: Measurement uncertainty arising from sampling: a guide to methods and approaches Eurachem (2007) ISBN 978094892626 6. Available from the Eurachem secretariat

Ramsey MH, Thompson M (2007) Uncertainty from sampling, in the context of fitness for purpose. Accredit Qual Assur 12:503-513. doi:10.1007/s00769-007-0279-0

Ramsey MH, Thompson M, Hale M (1992) Objective evaluation of the precision requirements for geochemical analysis using robust analysis of variance. J Geochem Explor 44:23-36. doi:10.1016/0375-6742(92 )90046-B

Reimann C, Filzmoser P (2000) Normal and lognormal data distribution in geochemistry: death of a myth. Consequences for the statistical treatment of geochemical and environmental data. Environ Geol 39:10011014. doi: $10.1007 / \mathrm{s} 002549900081$

Reimann C, Arnoldussen A, Boyd R, Finne TE, Nordgulen O, Volden T, Englmaier P (2006) The influence of a city on element contents of a terrestrial moss (Hylocomium splendens). Sci Total Environ 369:419 432. doi:10.1016/j.scitotenv.2006.04.026

Rostron PD, Ramsey MH (2012) Cost effective, robust estimation of measurement uncertainty from sampling using unbalanced ANOVA. Accredit Qual Assur 17:7-14. doi:10.1007/s00769-011-0846-2
Sadeghzadeh B (2013) A review of zinc nutrition and plant breeding. J Soil Sci Plant Nutr 13:905-927. doi:10.4067/S0718-95162013005000072

Sakalys J, Kvietkus K, Sucharová J, Suchara I, Valiulis D (2009) Changes in total concentrations and assessed background concentrations of heavy metals in moss in Lithuania and the Czech Republic between 1995 and 2005. Chemosphere 76:91-97. doi:10.1016/j.chemosphere.2009.02.009

Salo H, Bućko MS, Vaahtovuo E, Limo J, Mäkinen J, Pesonen LJ (2012) Biomonitoring of air pollution in SW Finland by magnetic and chemical measurements of moss bags and lichens. J Geochemical Explor 115:69-81. doi:10.1016/j.gexplo.2012.02.009

Samecka-Cymerman A, Kosior G, Kempers AJ (2006) Comparison of the moss Pleurozium schreberi with needles and bark of Pinus sylvestris as biomonitors of pollution by industry in Stalowa Wola (southeast Poland). Ecotoxicol Environ Saf 65:108-117. doi:10.1016/j. ecoenv.2005.05.009

Siewers U, Herpin U, Straßburg S (2000) Schwermetalleinträge in Deutschland. Moos-Monitoring 1995/96, Part 2. Geologisches Jahrbuch, Special Edition, SD 3: Gebrüder Borntraeger. Verlagsbuchhandlung, Stuttgart

Smagunova AN, Karpukova OM, Belykh LI, Malykh YM, Aprelkova NF, Kozlov VA (2004) Sampling errors in monitoring the pollution of environmental samples. J Anal Chem 59:1146-1152. doi:10.1023 /B:JANC.0000049714.19385.78

Stamenov J, Iovchev M, Vachev B, Gueleva B, Yurukova L, Ganeva A, Mitrikov M, Antonov A, Srentz A, Varbanov Z, Batov I, Damov K, Marinova E, Frontsayeva MV, Pavlov SS, Strelkova LP (2002) New results from air pollution studies in Bulgaria (Moss Survey 2000-2001). JINR Preprint E14-2002-204, Dubna

State G, Popescu IV, Radulescu C, Macris C, Stihi C, Gheboianu A, Dulama I, Nițescu O (2012) Comparative studies of metal air pollution by atomic spectrometry techniques and biomonitoring with moss and lichens. Bull Environ Contam Toxicol 89:580-586. doi:10.1007/s00128-012-0713-9

Sucharová J, Suchara I (2004) Current multi-element distribution in forest epigeic moss in the Czech Republic - a survey of the Czech national biomonitoring programme 2000. Chemosphere 57:1389-1398. doi:10.1016/j.chemosphere.2004.08.016

Szczepaniak K, Biziuk M (2003) Aspects of the biomonitoring studies using mosses and lichens as indicators of metal pollution. Environ Res 93: 221-230. doi:10.1016/S0013-9351(03)00141-5

Wadleigh MA (2003) Lichens and atmospheric sulphur: what stable isotopes reveal. Environ Pollut 126:345-351. doi:10.1016/S0269-7491 (03)00247-1

Wannaz ED, Carreras HA, Rodriguez JH, Pignata ML (2012) Use of biomonitors for the identification of heavy metals emission sources. Ecol Ind 20:163-169. doi:10.1016/j.ecolind.2012.02.022

Wolterbeek B (2002) Biomonitoring of trace element air pollution: principles, possibilities and perspectives. Environ Pollut 120:11-21. doi:10.1016/S0269-7491(02)00124-0

Wolterbeek HT, Verburg TG (2002) Judging survey quality: local variances. Environ Monit Assess 73:7-16

Xiao HY, Tang CG, Xiao HW, Liu XY, Liu C-Q (2010) Stable sulphur and nitrogen isotopes of the moss Haplocladium microphyllum at urban, rural and forested sites. Atmos Environ 44:4312-4317. doi:10.1016/j. atmosenv.2010.05.023

Zechmeister HG, Dullinger S, Hohenwallner D, Riss A, Hanus-Illnar A, Scharf S (2006) Pilot study on road traffic emissions (PAHs, heavy metals) measured by using mosses in a tunnel experiment in Vienna, Austria. Environ Sci Pollut Res Int 13:398-405. doi:10.1065 lespr2006.01.292

Zhou JL, Siddiqui E, Ngo HH, Guo W (2014) Estimation of uncertainty in the sampling and analysis of polychlorinated biphenyls and polycyclic aromatic hydrocarbons from contaminated soil in Brighton, UK. Sci Total Environ 497:163-171. doi:10.1016/j.scitotenv.2014.07.097 